\title{
Intermediates in the Ing-Manske reaction
}

\author{
O. M. Sinead Curley, Joan E. McCormick, R. Stanley McElhinney, \\ and T. Brian H. McMurry*
}

University Chemical Laboratory, Trinity College, Dublin 2, Ireland

E-mail:tmcmurry@tcd.ie

\section{Dedicated to Professor Tony McKervey on his 65th birthday}

(received 12 Feb 03; accepted 08 May 03; published on the web 17 May 03)

\begin{abstract}
Suggestions in the literature for the structures of the isolated intermediates formed in the IngManske reaction under a variety of conditions are either confirmed or revised. The $N$ alkylphthalimide reacts with hydrazine at room temperature or under to afford the 2-(Naminocarbamoyl)- $N$-alkylbenzamide. At higher temperatures, this cyclises to give the amine salt of phthalohydrazide. The amine can be isolated from either intermediate by acid, or from the salt with base.
\end{abstract}

Keywords: Ing-Manske reaction, phthalimides, hydrazinolysis

\section{Introduction}

The Gabriel synthesis of primary amines ${ }^{1}$ was greatly simplified when Ing and Manske ${ }^{2}$ reported that a preparative method involving treatment of $N$-a1ky1phthalimides $\mathbf{1}$ with hydrazine followed by acid afforded the corresponding primary amine $\mathbf{2}$ as its salt $\mathbf{2 . \mathbf { H } ^ { + }}$ and phthalohydrazide (2,3-dihydro-1,4-phthalazinedione) 3. Radenhausen ${ }^{3}$ was the first person to report (incidentally) the hydrazinolysis of an $N$-substituted phthalimide, though he did not identify all the products. Over the years, many experimental procedures have been recorded for different $N$-alkylphthalimide substrates, with variations in the molar proportions of hydrazine, solvent, reaction temperature and time, and conditions of acid/alkaline work-up. Workers frequently used the method without discussing the reaction details. Intermediates have been postulated, sometimes isolated, and had different structures assigned to them. We shall summarise the significant developments, and outline our own findings. 


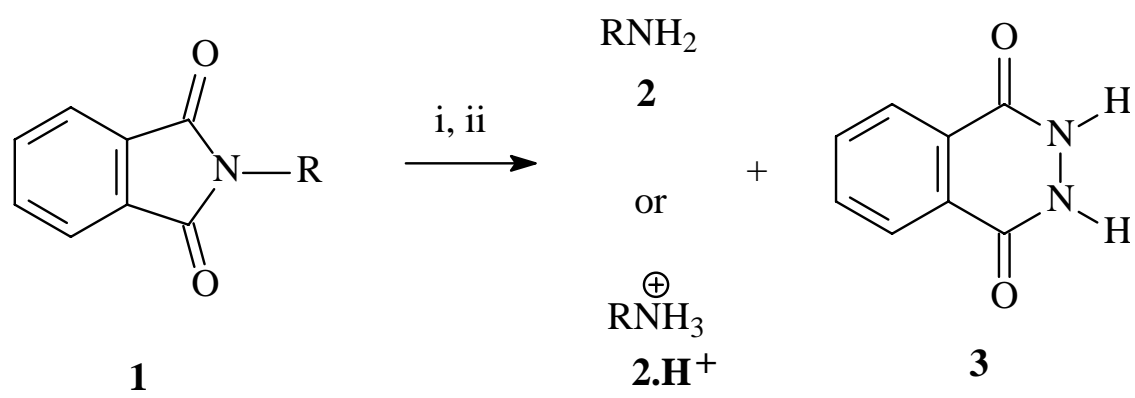

a, $\mathrm{R}=\mathrm{PhOCH}_{2} \mathrm{CHOHCH}_{2} \quad$ b, $\mathrm{R}=\mathrm{PhCH}_{2}$

Reagents: (i) $\mathrm{NH}_{2} \mathrm{NH}_{2}$, (ii) Heat or $\mathrm{H}^{\oplus}$

The reaction pathway can be imagined as follows. Attack of hydrazine on the phthalimide would give the amidohydrazide $\mathbf{4}$ which could then ring close to give either phthalohydrazide $\mathbf{3}$ plus amine 2, $N$-aminophthalimide 5 plus amine 2, or the phthalazinone $\mathbf{6}$. This last compound, and also the amidohydrazide 4, could be envisaged as unstable in acid, breaking down to phthalohydrazide 3 plus the amine salt. Three further complications involve the attack of the liberated amine $\mathbf{2}$ on unreacted phthalimide 1 to afford the diamide 7, the attack of hydrazine on the $\mathrm{N}$-aminophthalimide $\mathbf{5}$ to afford the dihydrazide $\mathbf{8}$, and thirdly the acidity of phthalohydrazide $\mathbf{3}$ so that relatively stable salts $\mathbf{9}$ are formed of it with the amine.<smiles>[R]Nc1n[nH]c(=O)c2ccccc12</smiles>
a, $\mathrm{R}=\mathrm{PhOCH}_{2} \mathrm{CHOHCH}_{2}$
b, $\quad \mathrm{R}=\mathrm{PhCH}_{2}$ 
<smiles>[R]N1C(=[NH2+])c2ccccc2C1=O</smiles>

1<smiles>[R]NC(=O)c1ccccc1C(=O)N[R]</smiles>

7<smiles>NNC(=O)c1ccccc1C(=O)NN</smiles><smiles></smiles>

9

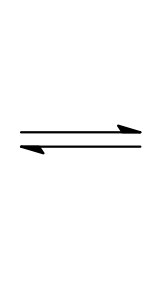<smiles>O=c1[nH][nH]c(=O)c2ccccc12</smiles>

3<smiles>[R19]N</smiles>

$9^{\prime}$
a, $\quad \mathrm{R}=\mathrm{PhOCH}_{2} \mathrm{CHOHCH}_{2}$
b, $\mathrm{R}=\mathrm{PhCH}_{2}$

In their original investigation in 1926, Ing and Manske ${ }^{2}$ chose (without evidence) a phthalazinone $\mathbf{6}$ as the intermediate in the reaction, and stated that it was converted to the products, $\mathbf{2 . \mathbf { H } ^ { + }}$ and $\mathbf{3}$ on treatment with acid. Later (1959), Roth ${ }^{4}$ in another system also adopted this type of structure, and produced analytical figures to support it, though his argument is weakened as calculations show that he had obtained greater than $100 \%$ yield. In 1993, the same type of intermediate was recorded uncritically by Toda et al. ${ }^{5}$ They had overlooked the work of Flitsch and Peters ${ }^{6}$ who already (1967) had synthesised compounds of the structure 6 by independent means, and shown that they were stable to acid under the conditions that converted the Ing-Manske intermediate to the amine salt.

Some years before, both Mosher ${ }^{7}$ and Barber and Wragg ${ }^{8}$ (1946) as part of a considerable effort to develop new anti-malarials examined a phthalimidopropylaminoquinoline. Reacting it with hydrazine in refluxing ethanol, the latter postulated the intermediates as $\mathbf{4}$ and the amine salt $\mathbf{9}$ of phthalohydrazide $\mathbf{3}$ but did not isolate them. However they did isolate and characterise the corresponding salt derived from $N$-benzylphthalimide. This has a different molecular formula from an intermediate of type $\mathbf{6}$, and would show different analytical figures. The role of acid would merely release the phthalohydrazide from its salt. Both sets of authors realised the 
possibility of alkali workup. Barber and Wragg also found that when they used $0.5 \mathrm{~mol}$ of hydrazine to $1 \mathrm{~mol}$ of phthalimide, appreciable quantities of the diamide were formed. Even with a 1:1 molar ratio, some diamide was among the products. Gibson and Bradshaw ${ }^{9}$ in 1968 in a review of the Gabriel synthesis favoured the amine salt of phthalohydrazide structure for the intermediate.

Petrow and Stephenson ${ }^{10}$ earlier (1953) had used the hydrazinolysis reaction (boiling ethanol) to prepare a series of hydroxyamines, and preferred the ring-opened amidohydrazide 4 as the intermediate. They showed that their compound was converted to the primary amine salt and phthalohydrazide on treatment with acid. The same type of structure was favoured by Connors and Ross (1960) ${ }^{11}$ (using ethanol as solvent at room temperature). 4 and 9 have, of course, the same molecular formula and would provide the same analytical figures.<smiles>Nc1cccc2c1C(=O)NC2=O</smiles>

10<smiles>Nc1cccc2c1C(=O)N(N)C2=O</smiles>

11<smiles>Nc1cccc2c(=O)[nH][nH]c(=O)c12</smiles>

12

Niyaz Khan ${ }^{12}$ in a kinetic study implicates the existence of 4, 5, 8 and 3 . Drew and Pearman ${ }^{13}$ had found that ring opening and subsequent closure of 4-aminophthalimide 10 using one equivalent of hydrazine gave $N, 4$-diaminophthalimide 11, while with two equivalents of hydrazine, it gave the six-membered aminophthalazinedione 12. Other substituted phthalimides gave the same result (4-chloro, 4,7-dichloro, 4,5,6,7- tetrachloro) while yet others (4-hydroxy, 5amino, and 5,6-dichloro) afforded only the phthalohydrazide under all conditions.

It seemed worthwhile to sort out the conflicting results, and to determine the structures of the intermediates.

\section{Results and Discussion}

We decided to repeat experiments using the substituted phthalimide 1a reported by Roth, ${ }^{4}$ which was very close in structure to those synthesised by Petrow and Stephenson ${ }^{10}$ - these carried $p$ chloro- and $p$-nitro-substituents on the phenyl ring. Using the conditions described by Roth (7.5 equivalents of hydrazine in $\mathrm{MeOH}$, reflux for $40 \mathrm{~min}$ ) and also those of Petrow and Stephenson (1 equivalent of hydrazine added to refluxing ethanol, followed by cooling), we obtained the same product. This proved to be the amine salt of phthalohydrazide $\mathbf{9 a}$. 
In the interests of simplifying the NMR spectra, any further experiments were carried out on $N$-benzylphthalimide 1b. Again under the conditions specified by $\operatorname{Roth}^{4}$ and also those described by Petrow and Stephenson ${ }^{10}$, the product was the amine salt $\mathbf{9 b}$. This compound also could be prepared by adding 1 equivalent of benzylamine to phthalohydrazide 3 . It is clear that both sets of workers obtained the amine salts $\mathbf{9}$ as intermediates in their systems, and were incorrect in their assignment of structure to their intermediates.

We also investigated the hydrazinolysis reaction at various temperatures, requiring the use of $\mathrm{DMF}$ as solvent. If the reaction is carried out under much milder conditions at $-15^{\circ} \mathrm{C}(1.1$ equivalents hydrazine, $14 \mathrm{~h}$ ), then another type of product was obtained in $76 \%$ yield. This proved to be the amidohydrazide $\mathbf{4} \mathbf{b}$, which was characterised by spectral analysis (see below). We also were able to react it with benzaldehyde to afford the corresponding hydrazone 13.

At $20^{\circ} \mathrm{C}$ (1.1 eq. hydrazine in DMF for $5 \mathrm{~h}$ ), the amidohydrazide $\mathbf{4 b}$ was the main product, but with $20 \%$ starting material. The reaction may not have gone to completion. At $50^{\circ} \mathrm{C}$ (same conditions, $5 \mathrm{~h}$ ), the recovered mixture (80\%) was the phthalohydrazide salt $\mathbf{9 b}, 65 \%$ ) with some amidohydrazide (30\%). While Petrow and Stephenson ${ }^{10}$ were evidently wrong, Connors and Ross $^{11}$ were almost certainly correct in their assignment of the amidohydrazide structure to their intermediate, and this type of structure can be given confidently to any intermediate isolated in a room temperature experiment. We also confirmed Barber and Wragg's observation that excess hydrazine hydrate was required in order to get a clean reaction and good yields of the amine salt 9b. The use of a 1:1 molar ratio of hydrazine and phthalimide gave rise to mixtures which were difficult to purify.

Treatment of either the amidohydrazide $\mathbf{4 b}$ or amine salt $\mathbf{9 b}$ with acid gave phthalohydrazide $\mathbf{3}$ and the amine as its salt $\mathbf{2 . \mathbf { H } ^ { + }}$.<smiles>O=C(NCc1ccccc1)c1ccccc1C(=O)N/N=C/c1ccccc1</smiles>

13<smiles>N#Cc1ccccc1C(N)=O</smiles><smiles>N=C1NC(=O)c2ccccc21</smiles>

14

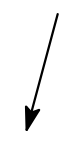<smiles></smiles>

6<smiles>O=C1N=C(NCc2ccccc2)c2ccccc21</smiles>

15

$\mathrm{b}, \mathrm{R}=\mathrm{Ph}$

c, $\mathrm{R}=\mathrm{H}$ 
In order to confirm that compounds of type $\mathbf{6}$ were not intermediates, we synthesised $\mathbf{6 b}$ using a method employed by Flitsch and Peters. ${ }^{6}$ Reaction of 2-cyanobenzamide ${ }^{14}$ with sodium hydroxide solution for a short period afforded the monoimino analogue 14 of phthalimide, ${ }^{14}$ which in turn reacted with benzylamine hydrochloride ${ }^{6}$ to give 3-benzyliminoisoindolin-1-one 15. This with hydrazine afforded $\mathbf{6 b}$ and 4 -aminophthalazin-1-one $\mathbf{6 c}{ }^{6}{ }^{6}$ In another attempt to synthesise $\mathbf{6 b}$ from 3 , we reacted the latter with phosphorus pentachloride, which gave a mixture of 1,4-dichlorophthalazine $\mathbf{1 6}$ and 4-chlorophthalazin-l-one 17. ${ }^{15}$ The former compound reacted with benzylamine to afford l-benzylamino-4-chlorophthalazine $18,{ }^{6}$ but we were unable to convert this into $\mathbf{6 b}$. Flitsch and Peters ${ }^{6}$ had been successful in a number of related reactions to make compounds of the general formula $\mathbf{6}$, but did not investigate the benzyl derivative. The monochloro compound $\mathbf{1 6}$ failed to react with benzylamine. We also made 4-methoxyphthalazin1-one $19,{ }^{16}$ in the hope that we could replace the methoxy-group using benzylamine. We were unsuccessful.<smiles>O=c1[nH][nH]c(=O)c2ccccc12</smiles>

3<smiles>COc1n[nH]c(=O)c2ccccc12</smiles>

19<smiles>Clc1nnc(Cl)c2ccccc12</smiles>

16<smiles>O=c1[nH]nc(Cl)c2ccccc12</smiles>

17

These results clarify which compounds earlier workers had isolated as intermediates during the hydrazinolysis reaction; this proceeds from $\mathbf{1}$ to give the amidohydrazide $\mathbf{4}$ that then cyclises to afford the amine salt $\mathbf{9}$. It is clear that the phthalazinone $\mathbf{6}$ is not an intermediate. Furthermore, no $\mathrm{N}$-aminophthalimide 5 was detected, even in the crude reaction mixtures as determined by NMR, though the kinetic scheme ${ }^{12}$ implies that it might not be found. Substituted analogues of this compound are implicated in the reactions of the corresponding phthalimides. ${ }^{13}$ 


\section{Structural assignments}

We measured the IR, ${ }^{1} \mathrm{H}$ - and ${ }^{13} \mathrm{C}-\mathrm{NMR}$ spectra of the various compounds described above. For comparison purposes, we also examined the spectra of phthalic acid and phthalic anhydride.In the IR spectra, phthalic anhydride shows peaks at 1852 and $1790 \mathrm{~cm}^{-1}, N$-benzylphthalimide at 1777 and $1711 \mathrm{~cm}^{-1}$, the benzylammonium salt of phthalohydrazide $9 \mathbf{b}$ at $1667 \mathrm{~cm}^{-1}$, the amidohydrazide $\mathbf{4 b}$ at $1648 \mathrm{~cm}^{-1}$, 3-benzyliminoisoindolin-l-one $\mathbf{1 5}$ at $1679 \mathrm{~cm}^{-1}$, and 4benzylaminophthalazin-1-one $\mathbf{6 b}$ at 1648 and $1595 \mathrm{~cm}^{-1}$.

The principal features of the ${ }^{1} \mathrm{H}-\mathrm{NMR}$ spectra that enable us to distinguish the various compounds are the methylene protons and the aromatic, excluding the phenyl protons. Where there is symmetry, the aromatic protons appear as an AA'BB' signal, and where there is not, as a more complex pattern. In the former category are $N$-benzylphthalimide $\mathbf{1} \mathbf{b}$ and the amine salt $\mathbf{9 b}$, and in the latter, $\mathbf{5 b}, \mathbf{1 5}$ and $\mathbf{4 b}$. The amine salt $\mathbf{9 b}$ is in the former category because of rapid proton exchange between the two hydrogens on the nitrogens (cf.9 and $\mathbf{9}^{\prime}$ ). All the methylene signals are singlets but at distinctive positions. Exceptionally that of $\mathbf{4} \mathbf{b}$ is a doublet as it couples to the neighbouring $\mathrm{NH}$. The $\mathrm{NH}$ signals themselves are also distinctive for the individual compounds.

Similar symmetry considerations also apply to the ${ }^{13} \mathrm{NMR}$ spectra and provide means of distinguishing between the different classes of compounds. The CO peak of the salt $\mathbf{9 b}$ occurs downfield $\left(\delta_{\mathrm{C}} 155.2\right)$ of those of the other compounds as expected from the deshielding effects of the anion.

\section{Experimental Section}

General Procedures. Melting points are uncorrected. The hydrazine hydrate solution used in some experiments refers to a $5 \mathrm{M}$ solution of $98 \%$ hydrazine hydrate in DMF. The ${ }^{1} \mathrm{H}$ - and ${ }^{13} \mathrm{C}-$ NMR spectra were measured on a Bruker MSL 300 spectrometer at 300 and $75 \mathrm{MHz}$ respectively. $\mathrm{d}_{6}$-DMSO was used as solvent and as internal standard. Chemical shifts are measured in ppm from TMS and coupling constants in Hertz. IR spectra were measured in $\mathrm{cm}^{-1}$ using a Perkin Elmer 883 IR or a Paragon 1000 FT-IR instrument in Nujol mulls.

$N$-(2-Hydroxy-3-phenoxypropyl)phthalimide ${ }^{\mathbf{1 0}}$ (1a). Pyridine $(0.1 \mathrm{ml})$ was added to a mixture of 1,2-epoxy-3-phenoxypropane ( $4.0 \mathrm{ml}, 30 \mathrm{mmol})$ and phthalimide $(4.41 \mathrm{~g}, 30 \mathrm{mmol})$ in ethanol (30 ml).The reaction mixture was refluxed for $1 \mathrm{~h}$. A further quantity of ethanol $(15 \mathrm{ml})$ was added and the mixture heated for a further $1.5 \mathrm{~h}$. On cooling, the product was collected. A further crop was obtained on partial evaporation of the filtrate. The combined crops were recrystallized from ethyl acetate - hexane to give the phthalimide $1 \mathrm{a}(7.57 \mathrm{~g}, 85 \%), \mathrm{mp} \cdot 108^{\circ} \mathrm{C}$ (lit. $\left.{ }^{4} 110^{\circ} \mathrm{C}\right) . \delta_{\mathrm{H}}$ $3.72\left(2 \mathrm{H}, \mathrm{m}, 3^{\prime}-\mathrm{CH}_{2}\right), 3.92\left(2 \mathrm{H}, \mathrm{d}, J 5.3,1^{\prime}-\underline{\mathrm{CH}}_{2}-\mathrm{N}\right), 4.16(1 \mathrm{H}, \mathrm{m}$, 2'- $\mathrm{CHOH}), 5.36(1 \mathrm{H}, \mathrm{d}, \mathrm{OH}), 6.85-6.94(3 \mathrm{H}, \mathrm{m}), 7.26(2 \mathrm{H}, \mathrm{t}, J$ 8.1) and 7.82-7.89 $(4 \mathrm{H}, \mathrm{m}$, all

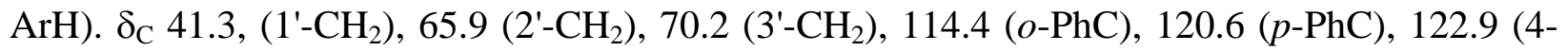


and 7-ArC), 129.4 (m-PhC), 131.8 (3a- and 7a-ArC) 134.2 (5- and 6-ArC), 158.4 (ipso-PhC) and 168.0 (CO x 2).

Hydrazinolysis of $\mathbf{N}$-(2-hydroxy-3-phenoxypropyl)phthalimide 1a (a) Roth's conditions. ${ }^{4}$ Hydrazine hydrate $25 \%$ (15 ml, $75 \mathrm{mmol}$ ) was added to the $N$-substituted phthalimide 1a (2.97g, $10 \mathrm{mmol}$ ) in methanol and the mixture refluxed for $40 \mathrm{~min}$. After cooling, the product was collected and recrystallized from ethanol to give the 2-hydroxy-3-phenoxypropylammonium salt 9a of 2,3-dihydrophthalazine-1,4-dione (2.20 g, 67\%), m.p. $176^{\circ} \mathrm{C}$ (lit ${ }^{9} 177^{\circ} \mathrm{C}$ ). Found: C, 61.9; $\mathrm{H}$, 5.85, N, 12.7. Calc. for $\mathrm{C}_{17} \mathrm{H}_{19} \mathrm{~N}_{3} \mathrm{O}_{4} \mathrm{C}$, 62.0; H, 5.8; N, 12.8\%). vmax 3600-3000, 1675, 1580, and 1450. $\delta_{\mathrm{H}} 2.70\left(2 \mathrm{H}\right.$, br m, $\underline{\mathrm{CH}_{2}}-\mathrm{NH}_{3}{ }^{+}$), 3.79-3.92, (m, 2- $\underline{\mathrm{CH}} \mathrm{OH}$ and 3- $\underline{\mathrm{CH}_{2}}$ ), 6.37 (5H, br s, $\mathrm{NH}_{3}{ }^{+}, \mathrm{NH}$ and $\left.\mathrm{OH}\right), 6.92(2 \mathrm{H}, \mathrm{m}, o-\mathrm{Ph}), 7.27$ (3H, m, $m$ - and $\left.p-\mathrm{Ph}\right), 7.84$ (2H, m, 6- and 7-ArH), and $8.05\left(2 \mathrm{H}, \mathrm{m}, 5-\right.$ and 8-ArH). $\delta_{\mathrm{C}} 43.6\left(1-\mathrm{CH}_{2}\right), 68.5(2-\mathrm{CH}), 69.9\left(3-\mathrm{CH}_{2}\right), 114.4(o-\mathrm{PhC})$, 120.5 ( $p$-PhC), 125.3 (5- and 7-ArC), 128.4 (4a- and 8a-ArC), 129.4 ( $m$-PhC), 131.8 (6- and 7ArC), 156.1 (CO) and 158.5 (ipso-PhC).

(b). Petrow and Stephenson's conditions. ${ }^{10}$ Hydrazine hydrate $50 \%$ (1 ml, $10 \mathrm{mmol}$ ) was added to a solution of the phthalimide $(2.97 \mathrm{~g}, 10 \mathrm{mmol})$ in boiling ethanol $(22 \mathrm{ml})$. On cooling, the precipitate was collected, and recrystallized from ethanol to give the same product (2.94g, 89\%),m.p. and mixed m.p., $176^{\circ} \mathrm{C}$ ). The IR and NMR spectra were identical to those recorded above.

Hydrazinolysis of $\boldsymbol{N}$-benzylphthalimide 1b. (a) Roth's conditions. ${ }^{4}$ Hydrazine hydrate $25 \%$ (15 ml, $7.5 \mathrm{mmol})$ was added to the phthalimide $\mathbf{1 b}(2.37 \mathrm{~g}, 10 \mathrm{mmol})$ in methanol (12 $\mathrm{ml})$, and the mixture refluxed for $40 \mathrm{~min}$. The precipitate which formed on cooling was collected as the benzylammonium salt $\mathbf{9 b}$ of 2,3-dihydrophthalazine-1,4-dione (1.91 g, 71\%) m.p. $>300^{\circ} \mathrm{C}$ (lit. ${ }^{8}$ $\left.342-346^{\circ} \mathrm{C}\right) . v_{\max } 3200-2400,1667$, and 1580. $\delta_{\mathrm{H}} 3.78\left(2 \mathrm{H}, \mathrm{s}, \mathrm{CH}_{2}\right), 5.92(4 \mathrm{H}, \mathrm{br} \mathrm{s}, \mathrm{NH}$ and $\mathrm{NH}_{3}{ }^{+}$), $7.20-7.38$ (5H, m, PhH), 7.85 (2H, dd, $J 3.3$ and 6.0, 6- and 7-ArH), and 8.08 (2H, dd, $J$ 3.3 and 6.0, 5- and 8-ArH); $\delta_{\mathrm{C}} 44.8\left(\mathrm{CH}_{2}\right), 125.2$ (5- and 8-ArC), 126.5 (4-PhC), 127.3 (3- and 5$\mathrm{PhC}$ ), 127.7 (1-PhC and 4a- and 8a-ArC), 128.1 (2- and 6-PhC), 132.2 (6- and 7-ArC), and 155.2 (CO).

(b) Petrow and Stephenson's conditions. ${ }^{\mathbf{1 0}}$ Hydrazine hydrate 25\% (1 ml, $\left.10 \mathrm{mmol}\right)$ was added to the phthalimide $\mathbf{1 b}(2.37 \mathrm{~g}, 10 \mathrm{mmol})$ in refluxing ethanol $(12 \mathrm{ml})$. On cooling, the solid was collected to give the salt $\mathbf{9 b}(2.31 \mathrm{~g}, 86 \%)$. It was identical to the product obtained from the reaction carried out under Roth's conditions. (c) At $-15^{\circ} \mathrm{C}$. Hydrazine hydrate solution (0.22 ml. $1.1 \mathrm{mmol}$ ) was added to $N$-benzylphthalimide (237 mg, $1 \mathrm{mmol})$ in DMF $(1.80 \mathrm{ml})$ at $-15^{\circ} \mathrm{C}$ and set aside for $14 \mathrm{~h}$. The precipitate formed was collected and the filtrate concentrated under reduced pressure to afford a further crop of 2-( $N$-aminocarbamoyl)- $N$-benzylbenzamide $\mathbf{4 b}$ (122 mg, 76\%) m.p. $128-130^{\circ} \mathrm{C}$ (shrinkage), decomposition $300^{\circ} \mathrm{C}$. (Found: C, 66.6; H, 5.55; N, 15.6. $\mathrm{C}_{15} \mathrm{H}_{15} \mathrm{~N}_{3} \mathrm{O}_{2}$ requires $\mathrm{C}$, 66.9; $\mathrm{H}, 5.6 ; \mathrm{N}, 15.6 \%$ ).

$\delta_{\mathrm{H}} 4.36\left(2 \mathrm{H}, \mathrm{d}, J\right.$ 2.8, NH- $\left.\underline{\mathrm{NH}}_{2}\right), 4.46$ (2H, d, $J$ 5.6, NH- $\left.\underline{\mathrm{CH}}_{2}\right), 7.21-7.53$ (9H, m,Ar and $\left.\mathrm{PhH}\right)$, $8.76\left(1 \mathrm{H}, \mathrm{t}, \underline{\mathrm{NH}}-\mathrm{CH}_{2}\right)$ and $9.44\left(1 \mathrm{H}\right.$, br s, $\left.\underline{\mathrm{NH}}-\mathrm{NH}_{2}\right) . \delta_{\mathrm{C}} 42.4\left(\mathrm{CH}_{2}\right), 126.6(p-\mathrm{PhC}), 127.2(\mathrm{~m}-$ $\mathrm{PhC}$ ), 127.7 and 127.8 (3- and 6-ArC), 128.2 (o-PhC), 129.3 and_129.4 (4- and 5-ArC), 134.9 and 136.4 (1- and 2-ArC), 139.5 (1-PhC), 167.7 and 168.0 (CO). 
(d) At $20^{\circ} \mathrm{C}$. Hydrazine hydrate solution $(0.22 \mathrm{ml}, 1.10 \mathrm{mmol})$ was added to $N$-benzylphthalimide (237 mg, $1 \mathrm{mmol}$ ) in DMF (1.80 ml) and the mixture stirred at $20^{\circ} \mathrm{C}$ for3 $\mathrm{h}$. Removal of the DMF under reduced pressure $(0.2 \mathrm{mmHg})$ gave a solid $(278 \mathrm{mg})$ which was shown to contain starting phthalimide and 2-( $N$-aminocarbamoyl)- $N$-benzylbenzamide $\mathbf{4 b}$ in the ratio 2:7. Recrystallization gave pure amidohydrazide $\mathbf{4 b}$.

(e) At $50^{\circ} \mathrm{C}$. Hydrazine hydrate solution $(0.22 \mathrm{ml}, 1.1 \mathrm{mmol})$ was added to $N$-benzylphthalimide (237 mg, $1 \mathrm{mmol})$ in DMF $(1.8 \mathrm{ml})$ and the solution heated to $50^{0} \mathrm{C}$ for $5 \mathrm{~h}$. The solvent was removed under reduced pressure to give a mixture (1:2) (215 $\mathrm{mg}$ ) of amidohydrazide $\mathbf{4 b}$ and benzylammonium salt $\mathbf{9 b}$. Recrystallisation gave the salt. The products were identified by comparison of their spectra with those of the compounds described above.

The benzylammonium salt 9b of 2,3-dihydro-phthalazine-1,4-dione. Benzylamine (1.07 ml, $10 \mathrm{mmol}$ ) was added to 2,3-dihydrophthalazine-1,4-dione (1.62 g, $10 \mathrm{mmol})$ in DMF (10 ml) and the solution heated at $50^{\circ} \mathrm{C}$ for $30 \mathrm{~min}$. Removal of the solvent afforded the salt $(2.47 \mathrm{~g}, 92 \%)$, which was identified by spectral comparison with the sample described above.

Acid treatment of the benzylammonium salt (9b). The above salt ( $279 \mathrm{mg}, 1 \mathrm{mmol}$ ), ethanol ( $2.5 \mathrm{ml})$ and concentrated hydrochloric acid $(2.5 \mathrm{ml})$ were heated at $50^{\circ} \mathrm{C}$ for $10 \mathrm{~min}$, and cooled. The product was 2,3-dihydrophthalazine-1,4-dione 3 (131 mg, 81\%). m.p. $>300^{\circ} \mathrm{C}$. The sample showed IR and NMR spectra identical to those of an authentic sample.

Acid treatment of 2(- $N$-aminocarbamoyl)- $N$-benzylhydrazide (4b). The amidohydrazide $\mathbf{4 b}$ (269 $\mathrm{mg}, 1 \mathrm{mmol})$, ethanol $(2.5 \mathrm{ml})$ and concentrated hydrochloric acid $(2.5 \mathrm{ml})$ were heated at $50^{\circ} \mathrm{C}$ for $10 \mathrm{~min}$. The precipitate (105 mg, 65\%) was collected, to give phthalhydrazide 3 , identical in all respects to an authentic sample.

2- ( $N$-Benzylideneaminocarbamoyl)- $N$-benzylbenzamide (13). Benzaldehyde $(0.056 \mathrm{ml}$, $0.55 \mathrm{mmol})$ and acetic acid $(0.1 \mathrm{ml})$ were added to a slurry of the amidohydrazide $4 \mathbf{b}$ (134 $\mathrm{mg}$, $0.5 \mathrm{mmol}$ ) in DMF (2 ml) at room temperature, and the mixture stirred for $3 \mathrm{~h}$. The solvent was removed in vacuo, and the residual syrup triturated with water $(4 \mathrm{ml})$. The solid was collected at the pump to give the benzylidene derivative (160 mg, 90\%), m.p. 135- $136^{\circ} \mathrm{C}, \lambda_{\max } 293 \mathrm{~nm}$. A sample was recrystallized from acetonitrile, (Found: C, 73.72; H, 5.3: N, 11.8. $\mathrm{C}_{22} \mathrm{H}_{19} \mathrm{~N}_{3} \mathrm{O}_{2}$ requires $\mathrm{C}$, 73.93; $\mathrm{H}, 5.35$; $\mathrm{N}, 11.75 \%)$.

3-Benzylaminoisoindolin-1-one (15). Benzylamine hydrochloride (240 mg, $1.6 \mathrm{mmol}$ ) was added to 3-iminoisoindolin-1-one $14^{6}(146 \mathrm{mg}, 1 \mathrm{mmol})$ in ethanol $(8 \mathrm{ml})$ and the mixture refluxed for1h. Removal of the solvent gave a solid 15 (150 mg, 64\%). 155 ${ }^{\circ} \mathrm{C}$, (Found: C, 74.6; $\mathrm{H}, 5.3 ; \mathrm{N}, 11.9$. $\mathrm{C}_{15} \mathrm{H}_{12} \mathrm{~N}_{2} \mathrm{O}$ requires $\left.\mathrm{C}, 74.6 ; \mathrm{H}, 5.1 ; \mathrm{N}, 11.9 \%\right) ; \delta_{\mathrm{H}} 4.71\left(2 \mathrm{H}, \mathrm{s}, \mathrm{CH}_{2}\right), 7.26-$ 7.41 (5H, m, Ph-H), $7.62-7.87(4 \mathrm{H}, \mathrm{m}, \mathrm{Ar}-\mathrm{H})$, and $11.10\left(1 \mathrm{H}\right.$, br s, NH); $\delta_{\mathrm{C}} 53.7\left(\mathrm{CH}_{2}\right), 121.6$ and 122.7 (4- and 5-ArC), 126.6 (p-PhC), 127.8 ( $m$-PhC), 128.3 (o-PhC), 131.3 (3a-ArC), 131.7 and 133.4 (5- and 6-ArC), 136.5 and 139.9 (7a-ArC and ipso-PhC), $149.6(\mathrm{C}=\mathrm{N})$ and169.0 $(\mathrm{C}=\mathrm{O}) ; v_{\max } 3269,3180,1679$, and 1616.

4-Benzylaminophthalazin-1-one $6 \mathrm{~b}$ and 4-aminophthalazin-1-one (6c). Hydrazine hydrate $100 \%$ (0.2 ml, $1 \mathrm{mmol}$ ) was added to 3- benzyliminoisoindolin-1-one (236 mg, $1 \mathrm{mmol}$ ) in ethanol. The solution was refluxed for $6 \mathrm{~h}$, and the solvent removed. The crude mixture was 
triturated with dilute hydrochloric acid ( $3 \times 10 \mathrm{ml}$ ), the insoluble portion collected, and crystallized to give 4-benzylaminophthalazin-1-one $\mathbf{6 b}(12 \mathrm{mg}) \mathrm{m} . \mathrm{p} .168^{\circ} \mathrm{C}, v_{\max } 3360,3191$,

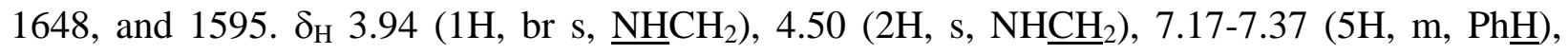

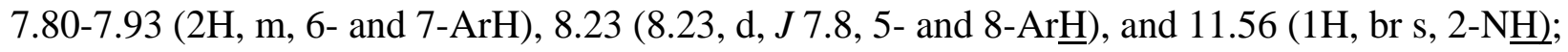
$\delta_{\mathrm{C}} 44.4\left(\mathrm{CH}_{2}\right), 123.1$ and 126.3 (6- and 7- ArC), 124.9 (4a- ArC), 126.4 (4-PhC0, 127.1 (3- and 5-PhC), 128.1 (2- and 6-PhC), 131.2 and 132.9 (5- and 8-ArC), 140.1 and 144.5 (8a-ArC and 1$\mathrm{PhC}$ ), 157.8 (4-ArC), and 174 (CO).

The acid-soluble fraction was neutralised to give 4-aminophthalazin-1-one, 6c (65 mg, 40\%), m.p. $270^{\circ} \mathrm{C}$ (lit. ${ }^{6}$ m.p. $266^{\circ} \mathrm{C}$ ). $v_{\max } 3259,3176,1656$, and $1599 . \delta_{\mathrm{C}} 5.97\left(2 \mathrm{H}, \mathrm{s}, \mathrm{NH}_{2}\right), 7.77-7.92$ (2H, m, 5- and 6-ArH), 8.06 (1H, d, J 7.9, 6- or 7-ArH), 8.21 (1H, d, J 7.9, 7- or 6-ArH), and 11.51(1H, s, NH); $\delta_{\mathrm{C}} 123.9$ (6- or 7-ArC), 124.9 (4a-ArC), 126.1 (7- or 6-ArC), 128.3 (8aC), 131.2 and 132.9 (5- and 8-ArC), 146.1 (4-ArC), and 158.1 (CO).

\section{References}

1. Gabriel, S. Chem. Ber. 1887, 20, 2224.

2. Ing, H.R.; Manske, R.H.F. J. Chem. Soc. 1926, 2349.

3. Radenhausen, R. J. Prakt. Chem. 1895, 52, 446.

4. Roth, H.J. Arch. Pharm. 1959, 194, 292.

5. Toda, F.; Soda, S.; Goldberg, I. J. Chem. Soc., Perkin Trans. 1 1993, 2357.

6. (a) Flitsch, W.; Peters, H. Angew. Chem., Int. Ed. 1967, 6, 173. (b) Chem. Ber. 1969, 102, 1304.

7. Mosher, H.S. J. Amer. Chem. Soc. 1946, 68, 1565.

8. $\quad$ Barber, H.J.; Wragg, W.R. Nature 1946, 158, 514; J. Chem. Soc. 1947, 1332.

9. Gibson, M.S.; Bradshaw, R.W. Angew. Chem., Int. Ed. 1968, 7, 928.

10. Petrow, V.; Stephenson, O. J. Pharm. Pharmacol. 1953, 5, 359.

11. Connors, T.A.; Ross, W.C.J. J. Chem. Soc. 1960, 2118.

12. Niyaz Khan, M. J. Org. Chem. 1995, 60, 4536; 1996, 61, 8063.

13. Drew H.D.K.; Pearman, F.H. J. Chem. Soc. 1937, 26.

14. Braun, A.; Tcherniac, J. Chem. Ber. 1907, 40, 2709.

15. Drew, H.D.K.; Hatt, H.H. J. Chem. Soc. 1937, 16.

16. Rowe, F.M.; Peters, A.T. J .Chem. Soc. 1933, 1331. 